\title{
PENGUNGKAPAN TANGGUNG JAWAB SOSIAL PERUSAHAAN SYARIAH (ISLAMIC SOCIAL REPORTING)
}

\author{
Fitri Selvia ${ }^{1}$, Lela Nurlaela Wati ${ }^{2}$, Bono Prambudi ${ }^{3}$ \\ ${ }^{1)}$ STIE Muhammadiyah Jakarta, fitriselvia274@gmail.com \\ ${ }^{2}$ STIE Muhammadiyah Jakarta, lela@ stiemj.ac.id \\ ${ }^{3)}$ STIE Muhammadiyah Jakarta, bono@stiemj.ac.id
}

\begin{abstract}
ABSTRAK
Konsep CSR kini tidak hanya berkembang di ekonomi konvensional, tetapi juga berkembang dalam ekonomi Islam. Konsep CSR dalam Islam disebut Islamic Social Reporting yang merupakan kerangka khusus untuk pelaporan pertanggungjawaban sosial yang sesuai dengan prinsip islam. Kerangka tersebut tidak hanya berguna bagi para pembuat keputusan Muslim, tetapi juga berguna membantu perusahaan Islam dalam pemenuhan kewajiban terhadap Allah SWT dan masyarakat. Metode penulisan ini menggunakan kajian pustaka melalui berbagai literature dengan tujuan menginformasikan kepada pembaca (informative research) mengenai tema-tema dalam pengungkapan tanggung jawab sosial pada perusahaan berbasis syariah.
\end{abstract}

Kata Kunci: Corporate Social Responcibility, Islamic Social Reporting

\begin{abstract}
The concept of corporate social responsibility (CSR) is now not only developing conventional economics, but also in the Islamic economy. The concept of CSR in Islam is Islamic Social Reporting, which is a special framework for reporting social responsibility in accordance with Islamic principles. The framework is not only useful for Muslim decision makers, but also useful for helping Islamic companies in fulfilling obligations towards Allah SWT and society. This writing method used literature review through various literature with the aim of informing the reader (informative research) about the themes in social responsibility disclosure in sharia-based companies.
\end{abstract}

Keywords: Corporate Social Responsibility, Islamic Social Reporting

\section{PENDAHULUAN}

Corporate Social Responsibility (CSR) merupakan sebuah gagasan yang menjadikan perusahaan tidak lagi dihadapkan pada tanggung jawab yang berpijak pada single bottom line dalam bentuk ekonomi atau nilai perusahaan saja, tetapi juga berpijak pada triple bottom line yaitu tanggung jawab terhadap masalah sosial dan lingkungan. Triple bottom line reporting 


\section{JURNAL AKUNTANSI, Vol. 7, No. 2, November (2018)}

merupakan laporan yang memberikan informasi mengenai pelaksanaan kegiatan ekonomi, sosial dan lingkungan dari sebuah entitas. Apabila prinsip triple bottom line dapat diimplementasikan dengan baik, maka akan menunjukkan akuntabilitas perusahaan tidak hanya untuk kegiatan ekonomi mereka, tetapi juga untuk pelaksanaan kegiatan social dan lingkungan (Deegan, dalam Wati, 2017).

Tanggung jawab sosial sering dianggap inti dari etika bisnis bahwa perusahaaan tidak hanya mempunyai kewajiban-kewajiban ekonomi dan legal (artinya kepada pemegang saham atau stakeholder) saja tetapi tanggung jawab sosial dari perusahaan merujuk pada semua hubungan yang terjadi antara sebuah perusahaan dengan semua stakeholder termasuk di dalamnya adalah pelanggan, pegawai, komunitas, pemilik atau investor dan pemerintah. Manfaat yang dapat diperoleh perusahaan setelah melaksanakan kegiatan corporate social responsibility (CSR) pertama perusahaan akan terhindar dari adanya reputasi negatif sebagai perusak lingkungan yang hanya mengejar keuntungan jangka pendek, kedua perusahaan akan mendapatkan rasa hormat dari masyarakat yang membutuhkan perusahaan seperti karyawan dan pelanggan, dan ketiga perusahaan akan terhindar dari gangguan lingkungan sekitar sehingga perusahaan akan terus menjalankan operasi bisnisnya dengan lancar serta tujuan utama perusahaan akan dapat menjamin kelangsungan hidup usahanya untuk jangka panjang (Kamaludin dan Indriani, 2012).

Konsep CSR kini tidak hanya berkembang di ekonomi konvensional, tetapi juga berkembang dalam ekonomi Islam. Konsep CSR dalam Islam erat kaitannya dengan perusahaanperusahaan yang menjalankan kegiatan bisnis sesuai dengan konsep syariah yang diharapkan perusahaan tersebut dapat melakukan tanggung jawab sosial perusahaan secara Islami. Pengungkapan ISR pertama kali dikemukakan oleh Haniffa (2002) lalu dikembangkan secara lebih ekstensif oleh Othman et al. (2009) di Malaysia. Haniffa (2002) mengungkapkan bahwa adanya keterbatasan dalam pelaporan sosial konvensional sehingga ia mengemukakan kerangka konseptual Islamic Social Reporting berdasarkan ketentuan syariah yang tidak hanya membantu pengambilan keputusan bagi pihak muslim melainkan juga untuk membantu perusahaan dalam melakukan pemenuhan kewajibannya terhadap Allah Subhanaahu wa Ta'ala dan masyarakat.

Perusahaan yang terdaftar di dalam Daftar Efek Syariah terus mengalami peningkatan dari tahun ke tahun. Berturut-turut dari tahun 2014, 2015, 2016, dan 2017 jumlah perusahaan yang listing di Daftar Efek Syariah adalah 322, 328, 345, dan 375 perusahaan. Kapitalisasi pasar saham syariah pun terus mengalami peningkatan dari tahun 2011 sebesar Rp. 1,968,091.37 Milyar menjadi Rp 2,288,015.67 Milyar di tahun 2017 (OJK, 2018). Hal ini menggambarkan semakin meningkatnya kesadaran perusahaan akan potensi bisnis dengan prinsip syari'ah yang berkeadilan dan bersih dari unsur-unsur riba. Di sisi lain dengan mengeluarkan saham syari'ah, perusahaan dapat mengambil keuntungan dari fleksibilitas perdagangan saham syari' ah, saham syari'ah dapat diperdagangkan kepada muslim dan non muslim di bursa konvensional maupun syari'ah sementara saham konvensional hanya dapat diperdagangkan di bursa konvensional saja. Sehingga diperlukan adanya suatu kajian yang komprehensif mengenai Pengungkapan ISR di Indonesia.

Tujuan dari penulisan artikel ini adalah menjelaskan konsep Pengungkapan Corporate Social Responsibility pada perusahaan Islam di Indonesia.

\section{METODE PENULISAN}

Metode penulisan ini berdasarkan kajian pustaka melalui berbagai literature dengan tujuan menginformasikan kepada pembaca (informative research). Analisis pada penelitian ini menggunakan desain penelitian deskriptif (descriptive research) yaitu prosedur penelitian yang 


\section{JURNAL AKUNTANSI, Vol. 7, No. 2, November (2018)}

menghasilkan data desriptif berupa kata-kata tertulis dari orang-orang dan perilaku yang diamati, didukung dengan studi literatur atau studi kepustakaan berdasarkan pendalaman kajian pustaka (Wati, 2017).

\section{PEMBAHASAN}

\section{Pasar Modal Syariah}

Pasar modal (capital market) merupakan pasar untuk berbagai instrument keuangan jangka panjang yang biasa di perjual belikan, baik dalam bentuk utang, ekuitas(saham), instrument derivative maupun instrument lainnya, (Nurhayati \& wasilah, 2008), sedangkan menurut menurut fatwa DSN-MUI No. 40/DSNMUI/X/2003, pasar modal adalah kegiatan yang bersangkutan dengan penawaran umumdan perdagangan efek, perusahaan public yang berkaitan dengan efek yang diterbitkan, serta lembaga dan profesi yang berkaitan dengan efek. Pasarmodal memiliki peranan penting dalam pembangunan nasional sebagai salah satu sumber pembiayaan bagi dunia usaha dan wadah investasi bagi masyarakat.

Dengan demikian, pasar modal dapat diartikan sebagai salah satu alternatif sumber pendanaan bagi perusahaan dan sarana investasi bagi pemilik modal. Implementasinya adalah perusahaan dapat memperoleh pendanaan melalui penerbitan efek dan pemilik modal dapat melakukan investasi di pasar modal melalui pembelian efek tersebut. Dalam rangka mengakomodasi kebutuhan masyarakat yang memiki motif investasi sesuai syariah islam serta di landasi keyakinan akan potensi keyakinan berkembangnya pasar modal syariah, Badan pengawas pasar modal dan lembaga keuangan (Bappepam-LK) dalam masater plan pasar modal Indonesia telah merencanakan dua strategi utama pengembangan pasar modal berbasis syariah islam (Arifin, 2006 dalam Ayu, 2010) pada tahun 2000 Bappepan-LK dan PT Danareksa Investment Management memunculkan indeks saham berbasis syariah islam yakni Jakarta Islamic Index (JII). Kehadiran JII menjadi milestone bagi pasar modal syariah islam diIndonesia, selanjutnya mulai hadir fatwa No.40/DSN-MUI/X/2003 tentang psar modal dan pedoman umum penerapan prinsip syariah di bidang pasar modal. Berbagai kebijakan dan fatwa ini di lakukan untuk memudahkan pengambilan keputusan investor muslim dalam berinvestasi.

Adapun perbedaan antara Indeks Saham Syariah Indonesia dengan Jakarta Islamic Index (JII) ini hanya terdiri dari 30 saham syariah yang tercatat di Bursa Efek Indonesia (BEI) sedangkan Indeks Saham Syariah Indonesia merupakan cerminan dari pergerakan sham-saham yang masuk dalam Daftar Efek Syariah (DES) yang dikeluarkan oleh BAPEPAM dan LK. ISSI diluncurkan pada tanggal 12 Mei 2011, indeks ini mencerminkan pergerakan saham yang terdaftar dalam Daftar Efek Syariah (DES) yang dikeluarkan oleh Bapepam-LK pada November 2007 yang kemudian DES sebagai satu-satunya rujukan mengenai efek syariah yang ada di Indonesia (dalam situs BEI mengenai syariah).Indeks ini sebagai acuan bagi investor untuk berinvestasi dalam basis syariah. Indeks ini mengacu pada ketentuan yang telah ditetapkan oleh AAOIFI.

\section{Legitimacy and Stake Holder Theory}

Gray et al. (1995) mengatakan bahwa dasar pemikiran teori legitimasi adalah organisasi atau perusahaan akan terus berlanjut keberadaannya jika masyarakat menyadari bahwa organisasi beroperasi untuk sistem nilai yang sepadan dengan sistem nilai masyarakat itu sendiri.

Teori legitimasi menganjurkan perusahaan untuk meyakinkan bahwa aktivitas dan kinerjanya dapat diterima oleh masyarakat. Perusahaan menggunakan laporan tahunan mereka untuk menggambarkan tanggung jawab lingkungan, sehingga mereka diterima oleh masyarakat. Dengan adanya penerimaan dari masyarakat tersebut diharapkan dapat meningkatkan nilai 


\section{JURNAL AKUNTANSI, Vol. 7, No. 2, November (2018)}

perusahaan sehingga dapat meningkatkan laba perusahaan. Hal tersebut dapat mendorong atau membantu investor dalam melakukan pengambilan keputusan investasi. Salah satu faktor yang banyak dibahas oleh peneliti mengenai motovasi manajer untuk melakukan pengungkapan sosial lingkungan adalah untuk mendapatkan legitimasi dari masyarakat khususnya atas kelangsungan organisasi.

Teori stakeholders menyatakan bahwa perusahaan bukanlah entitas yang hanya beroperasi untuk kepentingannya sendiri, namun harus memberikan manfaat bagi stakeholders (pemegang saham, kreditor, supplier, pemerintah, masyarakat, analisis dan pihak lain). Dengan demikian keberadaan suatu perusahaan sangat dipengaruhi oleh dukungan yang diberikan oleh stakeholders kepada perusahaan tersebut. Teori stakeholders merupakan salah satu teori yang mendasari pengungkapan sosial. Teori stakeholders dapat mendeskripsikan faktor Islamic Social Reporting (ISR) dalam penelitian ini. Teori stakeholders menyatakan bahwa operasi perusahaan tidak hanya untuk kepentingan perusahaan itu sendiri, tetapi juga untuk kepentingan pihak lain seperti stakeholders dan masyarakat.

\section{CSR \& ISR di Indonesia}

Konsep CSR tidak hanya berkembang di ekonomi konvensional, tetapi juga berkembang di ekonomi islam. Dewasa ini semakin banyak perusahaan-perusahaan yang menerapkan prinsip syariah dalam kegiatan bisnisnya. Salah satu aspek yang mendapat sorotan agar sesuai dengan prinsip-prinsip Islam adalah tanggung jawab sosial perusahaan. Siwar dan Hossain (2009) memaparkan bahwa nilai-nilai Islam yang dibawa oleh Nabi Muhammad SAW juga dapat digunakan sebagai landasan tanggung jawab sosial perusahaan sama seperti konvensional.

Pelaporan tentang CSR perusahaan yang semula bersifat sukarela menjadi bersifat wajib dengan adanya Undang-Undang Nomor 40 Tahun 2007 tentang Perseroan Terbatas bahwa laporan tahunan harus memuat beberapa informasi, salah satunya adalah laporan pelaksanaan tanggung jawab sosial dan lingkungan, sedangkan pelaporan sosial syariah, Islamic Social Reporting (ISR) masih bersifat sukarela, sehingga pelaporan CSR setiap perusahaan syariah menjadi tidak sama. Pelaporan yang tidak sama tersebut disebabkan tidak adanya standar yang baku secara syariah tentang pelaporan CSR syariah di Indonesia.

\section{Islamic Social Reporting (ISR)}

Salah satu bentuk akuntabilitas dalam perspektif ekonomi Islam adalah pelaporan tanggung jawab sosial perusahaan yang sesuai denganp rinsip syariah. Sedangkan dalam sisitem konvensional Haniffa (2002) berpendapat bahwa pelaporan tanggung jawab sosial perusahaan pada sistem konvensional hanya berfokus pada aspek material dan moral. Ia memandang bahwa perlu adanya kerangka khusus untuk pelaporan pertanggungjawaban sosial yang sesuai dengan prinsip islam. Kerangka tersebut tidak hanya berguna bagi para pembuat keputusan Muslim, tetapi juga berguna membantu perusahaan Islam dalam pemenuhan kewajiban terhadap Allah SWT dan masyarakat. Kerangka ini dikenal dengan sebutan Islamic Social Reporting (ISR). Prinsip syariah merupakan landasan dasar atas terbentuknya Islamic Social Reporting yang komprehensif. Prinsip syariah dalam Islamic Social Reporting menghasilkan aspek-aspek material, moral, dan spiritual yang menjadi fokus utama dari pelaporan tanggung jawab sosial perusahaan. Islam telah menjelaskan cukup jelas mengenai hak dan kewajiban bagi individu maupun bagi organisasi berdasarkan Al-Quran dan Hadist. Hal tersebut dikarenakan Islam adalah agama yang secara lengkap mengatur seluruh aspek kehidupan manusia di muka bumi. Siwar dan Hossain (2009) menyatakan bahwa landasan dasar dari agama Islam adalah aqidah (belief and faith), ibadah 
(worship), dan akhlaq (morality and ethics). Selain itu, ada prinsip lain yang sangat mendasar bagi setiap Muslim yakni tauhid (mengesakan Allah Subhanallahu wa Ta'ala) dalam beribadah dan tidak menyekutukan-Nya yang sesuai dengan firman Allah Subhanallahu wa Ta'ala dalam AL-Quran surat Ali Imran ayat 64 mengenai orang yang berhak menyandang gelar Muslim:

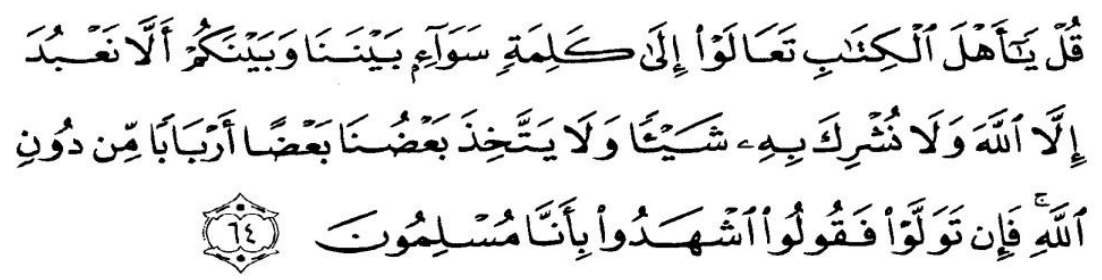

"Katakanlah, "Hai ahli kitab, marilah (berpegang kepada suatu kalimat (ketetapan) yang tidak ada perselisihan antara kami dan kamu, bahwa tidak kita sembah kecuali Allah dan tidak kita persekutukan. Dia dengan sesuatu pun dan tidak (pula) sebagian kita menjadikan sebagian yang lain sebagai Tuhan selain Allah."Jika mereka berpaling, maka katakanlah kepada mereka, "Saksikanlah bahwa kami adalah orang-orang yang berserah diri (kepada Allah)."

Ayat di atas menerangkan bahwa orang-orang yang berhak dikatakan seorang Muslim adalah orang-orang yang menjadikan tauhid sebagai agamanya. Orang-orang tersebut kelak akan mendapatkan keuntungan-keuntungan yang telah Allah SWT janjikan kepada mereka.

Accounting and Auditing Organization for Islamic Financial Institutions (AAOIFI) menetapkan standar CSR yang disesuaikan dengan perspektif Islam. Tetapi, standar yang ditetapkan oleh AAOIFI belum menyebutkan item-item yang terkait dengan CSR yang seharusnya diungkapkan. Lalu, standart yang ditetapkan oleh AAOIFI kemudian dikembangkan oleh beberapa peneliti yang selanjutnya penelitian tersebut menghasilkan Islamic social reporting.

Pengungkapan ISR adalah kumpulan indeks pelaporan tanggung jawab sosial yang sudah ditetapkan oleh AAOFII yang sesuai dengan syariah dan kemudian dikembangkan oleh masingmasing peneliti berikutnya (Haniffa, 2002; Maali et al., 2006; Ousama \& Fatima, 2006; Sulaiman, 2005; dan Othman et.al,2009). Indeks Islamic Social Reporting yang dirancang oleh Othman et al. (2009) adalah pengembangan indeks yang diadaptasi dari Haniffa (2002). Haniffa mengembangkan laporan Islam berdasarkan lima tema: Pendanaan dan Investasi, Produk, Karyawan, Masyarakat dan Lingkungan. Sedangkan Othman mengembangkan pengungkapan ISR menjadi enam tema yaitu Pendanaan dan Investasi, Produk dan Jasa, Karyawan, Masyarakat, Lingkungan, dan Tata Kelola Perusahaan. Dalam penelitian ini, penulis menggunakan indeks Islamic Social Reporting yang dirancang oleh Othman et al. (2009), penulis akan melakukan sedikit penyesuaian atas indeks-indeks tersebut dengan menyesuaikan indeks-indeks yang tidak bisa diterapkan di Indonesia, sama dengan yang telah dilakukan oleh peneliti sebelumnya yaitu Ayu (2010) dan Raditya (2012). Berikut adalah enam tema pengungkapan dalam kerangka indeks Islamic Social Reporting (ISR) yang digunakan dalam penulisan ini :

a. Pendanaan dan Investasi (Finance \& Investment)

Item pengungkapan yang termasuk dalam tema pendanaan dan investasi adalah pengungkapan mengenai informasi atas sumber pendanaan dan investasi perusahaan apakah mengandung interest-free (Riba) dan speculative-free (Gharar) yang sangat diharamkan 


\section{JURNAL AKUNTANSI, Vol. 7, No. 2, November (2018)}

dalam syariah Islam. Selain itu terdapat juga pengungkapan mengenai zakat, kebijakan atas penghapusan hutang tak tertagih, dan pernyataan nilai tambah dari manajemen (Haniffa, 2002; Othman \& Thani, 2009).

Riba adalah tambahan yang disyaratkan dalam transaksi bisnis tanpa adanya aturan yang dibenarkan syariah atas penambahan tersebut. Hal yang menyebabkan riba dilarang adalah karena riba adalah transaksi yang tidak adil yang akan mengakibatkan pihak peminjam akan semakin miskin dan pihak yang memberi pinjaman akan semakin kaya (merugikan salah satu pihak), sehingga akan menyebabkan terputusnya hubungan baik antar masyarakat dalam bidang pinjam meminjam. Firman Allah SWT dalam AlQuran yang mengharamkan riba terdapat pada surat Al-Baqarah ayat 278-280:

Pada kondisi lingkungan bisnis sekarang ini, untuk menghindari transaksi riba dan gharar termasuk hal yang sulit untuk dilakukan oleh beberapa perusahaan karena mereka harus terlibat dengan aktivitas yang melibatkan organisasi luar negeri ataupun sistem ekonomi dan politik yang berlaku. Dalam kondisi yang darurat, salah satu pemikiran memperbolehkan adanya transaksi riba dan gharar tersebut secara temporer sampai saat ketika perekonomian tidak lagi didominasi oleh kapitalisme sedangkan pemikiran yang lain hanya memperbolehkan praktek transaksi riba dan gahrar tersebut boleh dilakukan ketika pada situasi ekstrim yang dapat menyebabkan hilangnya jiwa (Haniffa, 2002).

Sedangkan Gharar adalah suatu transaksi yang mengandung ketidakpastian yang disebabkan oleh incomplete information. Ketidak jelasan dapat terjadi dalam lima hal yaitu, dalam kuantitas, kualitas, harga, waktu penyerahan, dan akad. Transaksi ini dilarang karena salah satu pihak akan terzalimi walaupun pada awalnya tidak demikian (Nurhayati \& Wasilah, 2009). Menurut Arifin (2009) dalam Raditya (2012), adapun bentuk-bentuk transaksi gharar dalam ekonomi konvensional meliputi perdagangan tanpa penyerahan (future non delivery atau trading margin trading), short selling, melakukan transaksi pure swap, capital lease, future, warrant, option, hedging, dan transaksi-transaksi derivatif lainnya. Oleh karena pelarangan transaksi riba dan gharar tersebut, maka semua sumber penghasilan perusahaan yang berasal dari riba dan gharar harus dengan sangat jelas diidentifikasi, dilaporkan, dan diungkapkan.

Informasi pengungkapan lain masuk dalam tema ini adalah mengenai pembayaran zakat. Pengertian Haniffa (2002) atas zakat adalah pemberian harta tertentu dalam jumlah tertentu yang diwajibkan oleh Allah SWT untuk penyucian harta dan jiwa. Ayat Al-Quran yang mengandung perintah untuk membayar zakat adalah QS Al-Baqarah: 43

Informasi selanjutnya yang masuk dalam tema pendanaan dan investasi adalah pengungkapan mengenai kebijakan penghapusan piutang perusahaan. Dalam Islam transaksi hutang piutang adalah suatu hal yang diperbolehkan karena dengan memberikan hutang atau pinjaman kepada orang lain yang membutuhkan akan membantu orang tersebut. Apabila pihak yang tidak bisa membayar hutang tersebut maka ada baiknya apabila mereka diberikan penangguhan ataupun penghapusan, hal tersebut terdapat dalam surat Al-Baqarah ayat 280.

Pengungkapan selanjutnya yang harus diketahui dalam laporan tahunan perusahaan adalah pernyataan nilai tambah perusahaan. Menurut Nurhayati \& Wasilah (2009), pernyataan nilai tambah perusahaan adalah suatu usulan pengganti laporan laba rugi atau sebagai laporan tambahan atas laporan posisi keuangandan laporan laba rugi. Usulan ini mempertimbangkan bahwa dibandingkan kinerja operasional (laba bersih) unsur terpenting dalam akuntansi syariah 


\section{JURNAL AKUNTANSI, Vol. 7, No. 2, November (2018)}

adalah kinerja dari sisi pandang para stakeholders dan nilai sosial yang dapat didistribusikan secara adil kepada kelompok yang terlibat dengan perusahaan dalam menghasilkan nilai tambah. Selain itu laporan nilai tambah dianggap lebih sesuai dengan aktivitas ekonomi Islam yang adil dan beretika, serta sejalan dengan tujuan akuntabilitas dari akuntansi syariah, khususnya pendapatan dan beban yang harus ditanggung oleh publik. Akan tetapi di Indonesia standar yang mengatur dan mengharuskan penerapan laporan nilai tambah belum ada maka penerapanya masih belum lazim dilakukan di Indonesia. Penelitian Raditya (2012) mengasumsikan perusahaan telah mengungkapkan laporan nilai tambah berdasarkan pernyataan "nilai-tambah" yang tersurat dalam laporan tahunan yang biasanya terdapat pada visi dan misi perusahaan.

Dalam Othman et al. (2009) terdapat satu indeks pengungkapan lainnya yaitu Current Value Balance Shett akan tetapi dalam penelitian ini peneliti tidak memasukkannya dalam indeks pengungkapan ISR. Sesuai dengan pendapat Ayu (2010), klasifikasi current value balance sheet menjadi tidak relevan sebagai kriteria pengungkapan karena PSAK masih memberlakukan nilai historis atas nilai-nilai di neraca dan perusahaan di Indonesia berpedoman pada PSAK dan karena banyak perusahaan yang masih memberlakukan nilai historis atas nilai-nilai di neraca, maka dalam penelitian ini current value balance sheet tidak dimasukkan dalam indeks. Berdasarkan dengan penjelasan yang telah diberikan, pengungkapan yang termasuk dalam tema pendanaan dan investasi dapat dilihat pada tabel 1 .

\section{b. Produk dan Jasa (Product and Service)}

Item pengungkapan yang termasuk dalam tema produk dan jasa adalah pengungkapan atas pertanggung jawaban perusahaan terhadap produk yang diperjual belikan. Othman dan Thani (2010) menyatakan bahwa semua produk dan jasa yang ditawarkannya bebas dari kategori haram seperti alkohol, babi, senjata, judi, dan hiburan begitu juga dengan Haniffa (2002), produk maupun jasa yang ditawarkan kepada pelanggan atau konsumen harus diidentifikasi kehalalannya. Seluruh produk dan jasa yang termasuk dalam kategori haram seperti babi, minuman keras, senjata, judi, dan hiburan harus diidentifikasi bersama dengan persentase kontribusinya terhadap laba perusahaan. Seperti firman Allah SWT dalam QS AlBaqarah: 173

Menurut Muwazir dan Muhamad (2006) dalam Ayu (2010), informasi terkait produk dan jasa yang harus diungkapkan dalam laporan tahunan perusahaan adalah sebagai berikut:

1) Pernyataan yang menyatakan seluruh produk dan jasa telah disetujui oleh Dewan Syariah Nasional (Majelis Ulama Indonesia untuk di Indonesia)

2) Pernyataan yang mengambarkan rincian produk atau jasa yang diproduksi perusahaan dan efek sampingnya.

Informasi pengungkapan lain yang masuk dalam tema ini adalah pengungkapan mengenai produk yang ramah lingkungan. Allah SWT menciptakan alam supaya manusia dapat memenuhi kebutuhan hidupnya sehingga seharusnya manusia janganlah merusak alam baik secara langsung maupun tidak langsung. Salah satu bentuk perusakan alam tersebut bisa berupa pencemaran lingkungan yang disebabkan oleh limbah produk, baik limbah yang berasal dari bahan pembuatan produk ataupun kemasan produk. Oleh karena itu perusahaan hendaknya menciptakan produk ramah lingkungan atau tidak memberikan negatif pada lingkungan. Larangan Allah SWT atas berbuat kerusakan di muka bumi terdapat dalam surat Al A'raf ayat 56 


\section{JURNAL AKUNTANSI, Vol. 7, No. 2, November (2018)}

Berdasarkan dengan penjelasan yang telah diberikan, pengungkapan yang termasuk dalam tema produk dan jasa dapat dilihat pada tabel 1 .

c. Karyawan (Employee)

Item pengungkapan yang termasuk dalam tema karyawan adalah pengungkapan atas perlakuaan perusahaan terhadap karyawan. Haniffa (2002) dan Othman dan Thani (2010), karyawan harus diperlakukan dan dibayar dengan adil atau tepat dan pemberi kerja harus menjamin pemenuhan kewajiban dasar dan juga spiritual karyawan. Informasi-informasi yang harus diungkapkan terkait dengan gaji atau upah, jam kerja, hari libur, tunjangan, sifat pekerjaan, dukungan pendidikan dan pelatihan, kesehatan dan keselamatan, kesetaraan, dan peluang melaksanakan ibadah. Muwazir dan Muhamad (2006) dalam Ayu (2010), informasiinformasi mengenai karyawan yang harus diungkapkan bagi para investor muslim dalam laporan tahunan adalah sebagai berikut:

1) Pernyataan yang mengungkapkan informasi terkait remunerasi karyawan (gaji dan bonus).

2) Pernyataan yang merincikan kebijakan perusahaan atas peluang pelatihan atau pendidikan bagi karyawan.

3) Pernyataan yang merincikan kebijakan perusahaan atas kesejahteraan dan tunjangan karyawan seperti ketentuan keagamaan, hari libur, dan tunjangan kesehatan.

4) Pernyataan yang merincikan mengenai kebijakan perusahaan atas peluang yang sama bagi wanita dan kelompok minoritas.

5) Pernyataan yang merincikan kebijakan perusahaan atas lingkungan kerja yang kondusif bagi nilai etika Islami.

Dalam melakukan pekerjaan, baik pihak pemberi kerja maupun pekerja haruslah memenuhi konsep amanah dan adl (adil) dalam hal pemberian manfaat, yaitu pihak pemberi kerja mendapatkan manfaat dari tenaga kerja seperti terselesaikannya pekerjaan dengan hasil yang bagus dan pihak pekerja mendapat gaji ataupun upah yang setara dengan pekerjaan yang dilakukannya. Pelaksanaan kewajiban dan hak kedua belah pihak tersebut haruslah dilakukan secara adil. Keadilan konsep gaji ataupun upah juga terdapat dalam AlQuran QS At-Taubah: 105

Selain masalah upah, pemberi kerja juga harus memperhatikan pendidikan para karyawannya, oleh karena itu pendidikan dan pelatihan karyawan juga diperlukan supaya perusahaan mempunyai tenaga kerja yang berkualitas. Walaupun perusahaan memperhatikan kualitas tenaga kerja yang dimilikinya, Perusahaan juga harus memberikan kesempatan yang setara pada karyawan. Berdasarkandengan penjelasan yang telah diberikan, pengungkapan yang termasuk dalam tema karyawan dapat dilihat pada tabel 1.

d. Masyarakat (Society)

Item informasi yang termasuk dalam tema Masyarakat adalah memberikan pengungkapan mengenai tindakan apa saja yang perusahaan berikan untuk masyarakat. Haniffa (2002), menyatakan bahwa tema masyarakat memberikan pengungkapan mengenai konsep umma, amanah, dan adl yang menekankan pada pentingnya membagi tujuan umum dan menghilangkan penderitaan dalam masyarakat dan hal tersebut bisa terwujud melalui 


\section{JURNAL AKUNTANSI, Vol. 7, No. 2, November (2018)}

sadaqah (kegiatan sosial), waqf (kepercayaan) dan qard hassan (memberikan pinjaman tanpa keuntungan). Sadaqah/Shadaqah adalah segala bentuk nilai kebajikan yang tidak terikat oleh jumlah, waktu dan juga tidak terbatas pada materi tetapi juga dapat berbentuk non materi. Sadaqah/Shadaqah memiliki makna yang lebih luas dibandingkan dengan zakat dan infak karena shadaqah tidak hanya berarti mengeluarkan atau mendermakan harta, tetapi mencakup segala amal dan perbuatan baik dalam rangka mencari kerhidhaan Allah SWT (Asmarandhi et al., 2010). Waqf atau Wakaf adalah penahanan hak milik atas materi benda untuk tujuan menyedekahkan manfaat atau faedahnya (Asmarandhi et al., 2010). Sedangkan qard hassan adalah suatu pinjaman yang diberikan atas dasar kewajiban sosial saja, dimana pihak peminjam tidak dituntut untuk mengembalikan apapun kecuali pinjaman. Kesamaan atas ketiga aktivitas tersebut adalah mendorong seseorang ataupun perusahaan untuk melakukan perbuatan yang dapat membantu orang disekitarnya, baik berupa pinjaman ataupun pemberian. Sedangkan bagi masyarakat umum merupakan realisasi kepedulian sosial, yang akan dapat memperkecil kesenjangan sosial dan mencegah munculnya penyakit hati akibat kecemburuan sosial (Asmarandhi et al., 2010).

Sedangkan menurut Haniffa dan Hudaib (2004), dengan melakukan kegiatan shadaqah, waqf, dan qard al-hassan dapat menghapuskan ataupun memindahkan penderitaan dalam kehidupan sosial karena perusahaan membagi rezeki yang mereka miliki dengan masyarakat, dimana tindakan perusahaan dapat berupa mendukung komunitas ataupun kegiatan kampanye sosial pemerintah. Adapun ajakkan untuk melakukan ketiga perbuatan tersebut terdapat dalam ayat Al-Quran QS Al-Imran: 92:

Selain ketiga perbuatan tersebut, terdapat pula kegiatan lain yang dapat perusahaan lakukan untuk membantu masyarakat sekitarnya, seperti pemberian beasiswa, kegiatan sukarela, ataupun memberikan sponsor atas kegiatan yang diadakan masyarakat. Maali et al. (2006), perusahaan harus mengungkapan perannya dalam meningkatkan pembangunan ekonomi dan mengatasi masalah sosial seperti masalah perumahan, buta huruf, beasiswa, dan lainnya dari masyarakat tempat mereka beroperasi seperti yang tertulis dalam Al-Quran Surat Al Baqarah: 271.

Muwazir dan Muhamad (2006) dalam Ayu (2010), informasi-informasi terkait komunitas mayarakat yang harus diungkapkan dalam laporan tahunan adalah sebagai berikut:

1) Deskripsi kontribusi perusahaan terkait perbaikan dalam masyarakat seperti program dalam membantu menyelesaikan permasalahan sosial seperti kemiskinan, buta huruf, dan lain sebagainya.

2) Pernyataan atas kontribusi yang dibuat untuk mendukung tindakan organisasi lain dalam memberikan perbaikan kehidupan di masyarakat.

3) Deskripsi partisipasi perusahaan dalam aktivitas sosial pemerintah.

4) Deskripsi keterlibatan perusahaan dalam kegiatan amal seperti shadaqah dan waqf (donasi keagamaan).

Dalam penelitian Ayu (2010), pengungkapan kegiatan amal akan disatukan dengan pengungkapan saddaqah atau pemberian donasi. Hal tersebut dikarena akan cukup sulit untuk membedakan kedua item pengungkapan tersebut dalam laporan tahunan perusahaan, selain itu penelitian Muwazir dan Muhamad (2006) juga tidak membedakan kedua item pengungkapan. 


\section{JURNAL AKUNTANSI, Vol. 7, No. 2, November (2018)}

Sedangkan dalam penelitian Othman et al. (2009), kegiatan amal dibedakan dengan pemberian bantuan. Dalam penelitian ini, pengungkapan kegiatan amal dan pemberian bantuan atau donasi akan digabungkan menjadi satu mengikuti penelitian Ayu (2010). Berdasarkan dengan penjelasan yang telah diberikan, pengungkapan yang termasuk dalam tema masyarakat dapat dilihat pada tabel 1 .

\section{e. Lingkungan (Enviroment)}

Item ini memberikan pengungkapan mengenai tindakan perusahaan terkait dengan lingkunga. Haniffa (2002), konsep mizan (keseimbangan), I'tidal (pertengahan), khilafah, dan akhirat, menekankan pada konsep keseimbangan, pertengahan, dan tanggung jawab untuk menjaga lingkungan hidup, sehingga informasi yang terkait penggunaan sumber daya dan program-program yang dilaksanakan untuk melindungi lingkungan hidup, harus diungkapkan oleh perusahaan. Othman dan Thani (2010), perusahaan seharusnya tidak terlibat dalam aktivitas yang mungkin menghancurkan atau merusak lingkungan, sehingga informasi mengenai program perlindungan atas alam haruslah diungkapkan. Ayat Al-Quran yang menjelaskan mengenai perlakuan terhadap lingkungan adalah pada Surat Al-Baqarah ayat 205-206:

Muwazir dan Muhamad (2006) dalam Ayu (2010), pengungkapan yang terkait dengan lingkungan hidup adalah pengungkapan yang terkait dengan usaha melindungi ciptaan Allah. Pengungkapan tersebut antara lain adalah sebagai berikut:

1) Deskripsi kontribusi atau kegiatan perusahaan yang dilakukan untuk melindungi lingkungan hidup.

2) Deskripsi sifat dan jumlah yang dikeluarkan untuk konservasi lingkungan alam dan margasatwa.

3) Pernyataan yang mengindikasikan bahwa operasi perusahaan sesuai dengan hukum dan peraturan lingkungan hidup.

4) Pernyataan yang mengindikasikan bahwa operasi perusahaan tidak mencemarkan lingkungan (no-polluting).

5) Pernyataan yang mendeskripsikan pelatihan karyawan yang berhubungan dengan isu-isu lingkungan hidup.

Dalam penelitian Othman et al. (2009) terdapat pemisahan pengungkapan mengenai kegiatan yang dapat membahayakan margasatwa dengan konservasi lingkungan sedangkan dalam penelitian ini, penulis akan menggabungkan kedua pengungkapan tersebut seperti dalam penelitian Ayu (2010). Ayu (2010), menggabungkan kedua pengungkapan tersebut menjadi satu pengungkapan konservasi lingkungan berdasarkan deskripsi pada penelitian Muwazir dan Muhamad. Berdasarkan dengan penjelasan yang telah diberikan, pengungkapan yang termasuk dalam tema lingkungan dapat dilihat pada tabel 2.1.

\section{f. Tata Kelola Perusahaan (Corporate Governance)}

Sulaiman (2005) dalam Othman dan Thani (2010), perusahaan haruslah mengungkapkan semua aktivitas terlarang seperti praktik monopoli, manipulsi harga, perjudian, dan 


\section{JURNAL AKUNTANSI, Vol. 7, No. 2, November (2018)}

penimbunan barang yang dibutuhkan dan kegiatan melanggar hukum lainnya. Hal tersebut sesuai dengan Al-Quran Surat Al Baqarah ayat 42:

Aktivitas monopoli adalah suatu aktivitas dimana suatu pasar hanya memiliki satu penjual/pemain tunggal sehingga harga barang akan dikuasi oleh penjual tersebut dan pembeli hanya bisa mengikuti permintaan penjual. Monopoli biasanya dilakukan dengan membuat persyaratan-persyaratan untuk masuk dalam pasar tersebut. Penimbunan barang adalah aktivitas membeli sesuatu yang dibutuhkan masyarakat, kemudian menyimpannya, sehingga barang tersebut berkurang di pasaran dan mengakibatkan peningkatan harga. Sedangkan aktivitas manipulasi harga biasanya dilakukan dengan merekayasa permintaan, dimana salah satu pihak akan mengajukan penawaran dengan harga yang tinggi sehingga pembeli tertarik dan membeli barang tersebut dengan harga yang tinggi (Nurhayati \& Wasilah, 2009). Aktivitas monopoli, penimbunan barang, ataupun manipulasi harga adalah aktivitas yang dilarang dalam Islam, hal ini karena aktivitas-aktivitas tersebut akan merugikan orang lain.

Pengungkapan lainnya yang masuk dalam tema Tata Kelola Perusahaan adalah pernyataan status syariah. Muwazir dan Muhamad (2006) dalam Ayu (2010), menyatakan bahwa pengungkapan pada pernyataan misi perusahaan harus menyertakan:

1) Pernyataan yang menyatakan bahwa operasi perusahaan telah berdasarkan prinsip syariah

2) Pernyataan yang menyatakan bahwa tujuan utama perusahaan adalah untuk mencapai barakah (keberkahan) dan al-falah (kesuksesan di dunia dan di akhirat), dengan menekankan bahwa pentingnya keuntungan yang halal

Apabila perusahan telah mengungkapan kedua pernyataan tersebut dapat dikatakan bahwa perusahaan tersebut telah sangat sesuai dengan prinsip syariah. Akan tetapi kedua kriteria ini masih belum terdapat dalam kriteria saham ISSI, tetapi dalam penelitian ini penulis tetap memasukkan indeks pengungkapan ini untuk mengetahui keberadaan perusahaan yang masuk dalam daftar ISSI dan secara tegas menyatakan bahwa perusahaan tersebut berprinsip syariah.

Informasi pengungkapan lainnya adalah pengungkapan mengenai kebijakan anti korupsi dimana Othman et al. (2009) memasukkan indeks ini sebagai salah satu indeks pengungkapan dalam tema Tata Kelola Perusahaan. Korupsi dapat diartikan sebagai tindakan penyalahgunaan jabatan yang digunakan untuk mengambil harta atau hak milik orang lain. Sedangkan dalam perspektif hukum Islam Adapun pengertian yang termasuk makna korupsi dalam fiqh Islam adalah as-sariqah (pencurian), al-ghashab (penggunaan hak orang lain tanpa izin), al-ghulul (penyelewengan harta negara), ar-risywah (suap), al-khianah (khianat), dan al-haraabah (perampasan). Korupsi adalah tindakan yang dilarang oleh Allah SWT karena dapat merugikan banyak orang. Adapun pelarangan korupsi terdapat dalam ayat Al-Quran dan Hadits

Di Indonesia, untuk mengetahui pengungkapan pemegang saham yang muslim, pihak perusahaan maupun bursa saham tidak mempunyai data mengenai agama masing-masing pemegang saham. Sedangkan untuk informasi dewan pengurus, di Indonesia pengungkapan mengenai profile direksi tidak disertakan dengan keterangan agama. Oleh karena itu kedua indeks tersebut penulis mengikuti indeks Ayu (2010) yang hanya pengungkapan tentang profile direksi dan pemegang saham. Berdasarkan dengan penjelasan yang telah diberikan, pengungkapan yang termasuk dalam tema tata kelola perusahaan dapat dilihat pada tabel 1 . 
Tabel 1. Indikator Pengungkapan ISR

\begin{tabular}{|c|c|c|c|}
\hline No & Pokok-pokok pengungkapan & \multirow[t]{2}{*}{ Poin } & \multirow[t]{2}{*}{ Sumber referensi } \\
\hline A & TEMA PEMBIAYAAN DAN INVESTASI & & \\
\hline 1 & $\begin{array}{l}\text { Kegiatan yang mengandung riba (beban bunga dan } \\
\text { pendapatan bunga) }\end{array}$ & 1 & $\begin{array}{lr}\text { Haniffa } & (2002) \\
\text { Othman et } & \text { al. }(2009) \\
\text { Fitria dan } & \text { Hartatnti } \\
(2010) & \end{array}$ \\
\hline 2 & $\begin{array}{l}\text { Pengungkapan kegiatan yang mengandung gharar atau } \\
\text { tidak (hegding, future non delivery trading/margin } \\
\text { trading, arbitrage baik spot maupun forward, short } \\
\text { selling, pure swap, warrant, dan lain-lain) }\end{array}$ & 1 & $\begin{array}{l}\text { Haniffa (2002) Maali } \\
\text { et al. (2006) Othman et } \\
\text { al. (2009) Fitria dan } \\
\text { Hartanti (2010) }\end{array}$ \\
\hline 3 & Zakat & 1 & $\begin{array}{l}\text { Haniffa (2002) Maali } \\
\text { et al. }(2006) \text { Othman } \text { et } \\
\text { al. (2009) Fitria dan } \\
\text { Hartanti (2010) }\end{array}$ \\
\hline 4 & $\begin{array}{l}\text { Kebijakan atas keterlambatan pembayaran piutang dan } \\
\text { penghapusan piutang tak tertagih }\end{array}$ & 1 & $\begin{array}{l}\text { Maali et al. }(2006) \\
\text { Othman et al. }(2009) \\
\text { Fitria dan Hartanti } \\
(2010)\end{array}$ \\
\hline 5 & Pernyataan nilai tambah perusahaan & 1 & $\begin{array}{l}\text { Sulaiman dan Willet } \\
\text { (2003) Othman et al. } \\
\text { (2009) }\end{array}$ \\
\hline B & TEMA PRODUK DAN JASA & & \\
\hline 6 & Produk atau kegiatan operasi ramah lingkungan & 1 & Othman et al. (2009) \\
\hline 7 & Kehalalan produk & 1 & $\begin{array}{l}\text { Haniffa } \quad(2002) \\
\text { Othman et al. } 1(2009\end{array}$ \\
\hline 8 & Keamanan dan kualitas produk & 1 & O1thman et al. (2009) \\
\hline 9 & Pelayanan pelanggan & 1 & $\begin{array}{l}\text { Othman et al. (2009) } \\
\text { Fitria dan Hartanti } \\
(2010)\end{array}$ \\
\hline $\mathrm{C}$ & TEMA KARYAWAN & & \\
\hline 10 & Jam kerja & 1 & $\begin{array}{ll}\text { Haniffa } & (2002) \\
\text { Othman et } & \text { al. }(2009) \\
\text { Fitria dan } & \text { Hartanti } \\
(2010) & \end{array}$ \\
\hline 11 & Hari libur dan cuti & 1 & $\begin{array}{ll}\text { Haniffa } & (2002) \\
\text { Othman et } & \text { al. }(2009) \\
\text { Fitria dan Hartanti } \\
(2010)\end{array}$ \\
\hline 12 & Tunjangan & 1 & $\begin{array}{ll}\text { Haniffa } & (2002) \\
\text { Othman et } & \text { al. }(2009) \\
\text { Fitria dan } & \text { Hartanti } \\
(2010) & \end{array}$ \\
\hline 13 & Remunerasi & 1 & $\begin{array}{ll}\text { Haniffa } & (2002) \\
\text { Othman et } & \text { al. } \\
\end{array}$ \\
\hline
\end{tabular}




\begin{tabular}{|c|c|c|c|}
\hline & & & $\begin{array}{l}\text { Fitria dan Hartanti } \\
(2010)\end{array}$ \\
\hline 14 & $\begin{array}{l}\text { Pendidikan dan pelatihan kerja (pengembangan } \\
\text { sumber daya manusia) }\end{array}$ & 1 & $\begin{array}{l}\text { Haniffa (2002) Maali } \\
\text { et al. (2006) Othman et } \\
\text { al. (2009) Fitria dan } \\
\text { Hartanti (2010) }\end{array}$ \\
\hline 15 & Kesetaraan hak antara pria dan wanita & 1 & $\begin{array}{l}\text { Haniffa (2002) Maali } \\
\text { et al. (2006) Othman et } \\
\text { al. (2009) Fitria dan } \\
\text { Hartanti (2010) }\end{array}$ \\
\hline 16 & $\begin{array}{l}\text { Keterlibatan karyawan dalam diskusi manajemen dan } \\
\text { pengambilan keputusan }\end{array}$ & 1 & $\begin{array}{l}\text { Othman et al. (2009) } \\
\text { Fitria dan Hartanti } \\
(2010)\end{array}$ \\
\hline 17 & Kesehatan dan keselamatan kerja & 1 & $\begin{array}{ll}\text { Haniffa } & (2002) \\
\text { Othman et } & \text { al. }(2009) \\
\text { Fitria dan } & \text { Hartanti } \\
(2010 & \end{array}$ \\
\hline 18 & Lingkungan kerja & 1 & $\begin{array}{l}\text { Haniffa } \quad(2002) \\
\text { Othman et al. (2009) } \\
\text { Maali et al (2006) }\end{array}$ \\
\hline 19 & $\begin{array}{l}\text { Karyawan dari kelompok khusus (cacat fisik, mantan } \\
\text { narapidana, mantan pecandu narkoba) }\end{array}$ & 1 & Othman et al. (2009) \\
\hline 20 & $\begin{array}{l}\text { Karyawan tingkat atas melaksanakan ibadah bersama- } \\
\text { sama dengan karyawan tingkat menengah dan tingkat } \\
\text { bawah }\end{array}$ & 1 & $\begin{array}{l}\text { Othman et } \text { al. (2009) } \\
\text { Fitria dan Hartanti } \\
(2010)\end{array}$ \\
\hline 21 & $\begin{array}{l}\text { Karyawan Muslim diperbolehkan menjalankan ibadah } \\
\text { di waktu-waktu shalat dan berpuasa di saat Ramadhan }\end{array}$ & 1 & Othman et al. (2009) \\
\hline 22 & Tempat ibadah yang memadai & 1 & Othman et al. (2009) \\
\hline $\mathrm{D}$ & TEMA MASYARAKAT & & \\
\hline 23 & Sedekah, donasi, atau sumbangan & 1 & $\begin{array}{l}\text { Haniffa } \quad(2002) \\
\text { Othman et al. }(2009)\end{array}$ \\
\hline 24 & Wakaf Qard & 1 & $\begin{array}{l}\text { Haniffa } \quad(2002) \\
\text { Othman et al. }(2009)\end{array}$ \\
\hline 25 & Qard Hassan & 1 & $\begin{array}{l}\text { Haniffa (2002) Maali } \\
\text { et al. }(2006) \text { Othman } \text { et } \\
\text { al. (2009) }\end{array}$ \\
\hline 26 & Sukarelawan dari kalangan karyawan & 1 & Othman et al. $(2009$ \\
\hline 27 & Pemberian beasiswa sekolah & 1 & Othman et al. $(2009$ \\
\hline 28 & $\begin{array}{l}\text { Pemberian beasiswa sekolah } 1 \text { Othman et al. (2009) } 28 \\
\text { Pemberdayaan kerja para lulusan sekolah/kuliah } \\
\text { (magang atau praktik kerja lapangan) }\end{array}$ & 1 & Othman et al. $(2009$ \\
\hline 29 & Pembangunan tunas muda & 1 & Othman et al. $(2009$ \\
\hline 30 & Peningkatan kualitas hidup masyarakat miskin & 1 & Othman et al. $(2009$ \\
\hline 31 & Kepedulian terhadap anak-anak & 1 & Othman et al. (2009 \\
\hline 32 & $\begin{array}{l}\text { Kegiatan amal atau kegiatan sosial (bantuan bencana } \\
\text { alam, donor darah, sunatan masal, pembangunan } \\
\text { infrasturktur, dan lain-lain) }\end{array}$ & 1 & Othman et al. (2009 \\
\hline
\end{tabular}




\begin{tabular}{|c|c|c|c|}
\hline 33 & $\begin{array}{l}\text { Menyokong kegiatan-kegiatan kesehatan, hiburan, } \\
\text { olahraga, budaya, pendidikan, dan keagamaan. }\end{array}$ & 1 & Othman et al. (2009 \\
\hline $\mathrm{E}$ & TEMA LINGKUNGAN & & \\
\hline 34 & Konservasi lingkungan & 1 & $\begin{array}{l}\text { Haniffa (2002) Maali } \\
\text { et al. (2006) Othman et } \\
\text { al. (2009) Fitria dan } \\
\text { Hartanti (2010) }\end{array}$ \\
\hline 35 & $\begin{array}{l}\text { Kegiatan mengurangi efek terhadap pemanasan global } \\
\text { (minimalisasi polusi, pengelolaan limbah, pengelolaan } \\
\text { air bersih, dan lain-lain) }\end{array}$ & 1 & Othman et al. (2009) \\
\hline 36 & Pendidikan mengenai lingkungan & 1 & Othman et al. (2009) \\
\hline 37 & $\begin{array}{llll}\text { Pernyataan verifikasi independen atau audit } \\
\text { lingkungan }\end{array}$ & 1 & Othman et al. (2009) \\
\hline 38 & Sistem manajemen lingkungan & 1 & $\begin{array}{l}\text { Othman et al. (2009) } \\
\text { Fitria dan Hartanti } \\
(2010)\end{array}$ \\
\hline $\mathrm{F}$ & TEMA TATAKELOLA PERUSAHAAN & & \\
\hline 39 & Status kepatuhan terhadap syariah & 1 & Othman et al. (2009) \\
\hline 40 & Struktur kepemilikan saham & 1 & $\begin{array}{l}\text { Othman et al. (2009) } \\
\text { Fitria dan Hartanti } \\
(2010)\end{array}$ \\
\hline 41 & Profil Dewan Direksi & 1 & Othman et al. (2009) \\
\hline 42 & $\begin{array}{l}\text { Pengungkapan melakukan praktik monopoli usaha } \\
\text { atau tidak }\end{array}$ & 1 & $\begin{array}{l}\text { Othman et al. (2009) } \\
\text { Fitria dan Hartanti } \\
(2010)\end{array}$ \\
\hline 43 & $\begin{array}{l}\text { Pengungkapan melakukan praktik menimbun bahan } \\
\text { kebutuhan pokok atau tidak }\end{array}$ & 1 & $\begin{array}{l}\text { Othman et al. (2009) } \\
\text { Fitria dan Hartanti } \\
(2010)\end{array}$ \\
\hline 44 & $\begin{array}{l}\text { Pengungkapan melakukan praktik manipulasi harga } \\
\text { atau tidak }\end{array}$ & 1 & $\begin{array}{l}\text { Othman et al. (2009) } \\
\text { Fitria dan Hartanti } \\
(2010)\end{array}$ \\
\hline 45 & Pengungkapan adanya perkara hukum atau tidak & 1 & Othman et al. (2009) \\
\hline 46 & $\begin{array}{l}\text { Kebijakan anti korupsi (code of conduct, } \\
\text { whistleblowing system, dan lain-lain) }\end{array}$ & 1 & Othman et al. (2009) \\
\hline & TOTAL & 46 & \\
\hline
\end{tabular}

Sumber : Raditya (2012)

Nilai indeks tersebut diperoleh dengan metode content analysis pada laporan tahunan perusahaan. Metode content analysis merupakan teknik analis berbentuk dokumen dan teks yang berupa menguantifikasi isi menurut kategori (indeks) yang sudah ditetapkan, dengan cara sistematis dan dapat diulang-ulang. Adapun langkah-langkah yang dilakukan dalam melakukan content analysis :

1. Membuat daftar ISR sesuati dengan Othman et al. (2009) dengan beberapa penyesuian. ISR yang digunakan terdiri dari 6 kategori yaitu thema and investment theme, product and services theme, employee theme, society (community involvement) theme, environment theme dan corporate governance theme. 


\section{JURNAL AKUNTANSI, Vol. 7, No. 2, November (2018)}

2. Memberi nilai pada setiap komponen ISR secara dikotomi, yaitu 1 apabila komponen tersebut diungkapkan dan 0 apabila tidak diungkapkan.

3. Nilai yang diperoleh setiap perusahaan dijumlahkan untuk mendapatkan nilai total untuk mendapatkan indeks ISR.

Indeks yang digunakan dalam penelitian ini adalah indeks ISR tanpa pembobotan.

$$
\mathrm{ISR}=\frac{\text { Jumlah item yang diungkapkan perusahaan }}{\text { Total item indikator pengungkapan }}
$$

\section{Penutup}

Pengungkapan ISR adalah kumpulan indeks pelaporan tanggung jawab sosial yang sudah ditetapkan oleh AAOFII yang sesuai dengan syariah dan kemudian dikembangkan oleh masingmasing peneliti. Indeks Islamic Social Reporting yang dirancang oleh Othman et al. (2009) adalah pengembangan indeks yang diadaptasi dari Haniffa (2002). Haniffa mengembangkan laporan Islam berdasarkan lima tema: Pendanaan dan Investasi, Produk, Karyawan, Masyarakat dan Lingkungan. Sedangkan Othman mengembangkan pengungkapan ISR menjadi enam tema yaitu Pendanaan dan Investasi, Produk dan Jasa, Karyawan, Masyarakat, Lingkungan, dan Tata Kelola Perusahaan. Nilai indeks tersebut diperoleh dari laporan tahunan perusahaan dengan menggunakan metode content analysis.

Adapun saran dari hasil literature review yang penulis lakukan terhadap pengungkapan tanggung jawab social perusahaan syariah, penulis menyarankan kepada pihak terkait dalam hal ini Otoritas Jasa Keuangan untuk membuat list pengungkapan Islamic Social Reporting perusahaan, karena selama ini pengungkapan-pengungkapan yang dilakukan untuk melihat Islamic social reporting di Indonesia masih mengacu kepada tema pengungkapan yang dikembangkan oleh Haniffa (2002) dan Othman et. al. (2009) dan penyesuaian oleh para peneliti di Indonesia, sehigga berdampak terhadap hasil pengungkapan yang tidak seragam.

\section{Referensi:}

Asmarandhi, I., Pamindo, P., Fahlevi, M.A., \& Arkadia, A. (2010). Pengertian Zakat, Infaq, Shodaqah, dan Waqaf. April 16. Retrieved from http://www.ripiu.com/article/read/pengertian-zakat-infaq-shadaqah-dan waqaf)

Ayu D.F. (2010). Analiss pengaruh jenis industri, ukuran perusahaan, dan profitabilitas terhadap tingkat pengungkapan Islamic Social Reporting (ISR) pada perusahan yang masuk daftar Jakarta Islamic Index (JII). Skripsi Universitas Indonesia: Depok. (tidak dipublikasikan).

Fitria, S., \& Hartanti, D. (2010). Studi Perbandingan Pengungkapan Berdasarkan Global Reporting Initiative Indeks Dan Islamic Social Reporting Indeks. Simposium Nasional Akuntansi. Purwokerto. Proceeding.

Gray, Rob; Reza Kouhy and Simon Lavers. (1995). Methodological Themes: Constructing a Research Database of Social and Environmental Reporting by UK Companies. Accounting, Auditing and Accountability Journal. Vol. 8, No. 2, p. 78-101

Haniffa, R. (2002). Social reporting disclosure: an Islamic perspective. Indonesian Management \& Accounting Research, 1(2), 128-146. 


\section{JURNAL AKUNTANSI, Vol. 7, No. 2, November (2018)}

Haniffa, R. M., \& Cooke, T. E. (2002). Culture, corporate governance and disclosure in Malaysian corporations. Abacus, 38(3), 317-349.

Haniffa, R., Hudaib, M., \& Mirza, A. M. (2004). Accounting Policy Choice within the Shariah Islamiiah Framework. Discussion Papers In Accountancy And Finance, SOBE, University Of Exeter, 2, 4-19.

Kamaludin, dan Indriani. (2012). Manajemen Keuangan. Edisi Revisi. Bandung : CV. Mandar Maju.

Maali, B., Casson, P., \& Napier, C. (2006). Social reporting by Islamic banks. Abacus, 42(2), 266-289.

Nurhayati, S dan Wasilah. (2009). Akuntansi Syariah di Indonesia, Jakarta: Salemba Empat.

Raditya,A.N. (2012). Analisis faktor-faktor yang mempengaruhi tingkat pengungkappan Islamic social reporting (ISR) pada perusahaan yang masuk daftar efek syariah (DES). skripsi Universitas Indonesia: Depok (tidak dipublikasikan).

Republik Indonesia. (2007). Undang-Undang Nomor 40 Tahun 2007 tentang Perseroan Terbatas.

Siwar, C., \& Hossain, T. (2009). An analysis of Islamic CSR concept and the opinions of Malaysian managers. Management of Environmental Quality: An International Journal, 20(3), 290-298.

Wati, L.N. 2017. Metodologi Penelitian Terapan Bisnis: Aplikasi SPSS, EVIEWS, SmartPLS, dan AMOS. Bandung: Mujahid Press.

Widayuni, N., \& Harto, P. (2014). Faktor-Faktor yang Mempengaruhi Pengungkapan Corporate Social Responsibility pada Perbankan Syariah di Indonesia dan Malaysia (Doctoral dissertation, Fakultas Ekonomika dan Bisnis).

https://www.ojk.go.id 